\title{
Crustal structure of the eastern Acambay graben, Central Mexico, from integrated geophysical data
}

\author{
Jorge Arzate ${ }^{1}$, Pierre Lacan ${ }^{1, *}$, Fernando Corbo-Camargo ${ }^{1,2}$, Claudia Arango-Galván ${ }^{3}$, \\ Rafael Felix-Maldonado ${ }^{3,4}$, Jesús Pacheco ${ }^{5}$, and Rodrigo León-Loya ${ }^{4}$
}

${ }^{1}$ Centro de Geociencias, Universidad Nacional Autónoma de México, Campus Juriquilla, Blvd. Juriquilla 3001, 76230 Querétaro, Mexico.

${ }^{2}$ CONACyT - Centro de Geociencias, Universidad Nacional Autónoma de México,

Campus Juriquilla, Blvd. Juriquilla 3001, 76230 Querétaro, Mexico.

${ }^{3}$ Instituto de Geofísica, Universidad Nacional Autónoma de México, Ciudad Universitaria, 04510 Ciudad de México, Mexico.

${ }^{4}$ Posgrado Ciencias de la Tierra, Centro de Geociencias, Universidad Nacional Autónoma de México, Campus Juriquilla, 76230 Querétaro, Mexico.

${ }^{5}$ Universidad Autónoma de Aguascalientes, Centro de Ciencias del Diseño y de la Construcción, Aguascalientes, Ags., Mexico.

*placan@geociencias.unam.mx

\section{ABSTRACT}

The Acambay graben is a $\sim 70 \mathrm{~km}$ long E-W seismically active structure located within the Trans-Mexican Volcanic Belt (TMVB). Quaternary volcanism has contributed to shaping the graben morphology and reported hydrothermal activity suggests the existence of potential geothermal reservoirs. Our work aims at providing information about the unstudied subsurface structure of the graben using magnetotelluric (MT) soundings, as well as gravity and aeromagnetic data as preliminary work for near-future integrated $3 \mathrm{D}$ approach. We analyzed the distribution of magnetic anomalies and its relation to faulting using total field (TFM) aeromagnetic digital charts E14 and F14 (https://www.gob.mx/sgm) and through the analysis of the tilt derivative of TFM. The gravity and magnetic horizontal derivatives provided complementary results to constrain the location of the main fault and to contrast the response of the Pastores and Acambay-Tixmadejé faults. For the subsurface interpretation, we present the results of a $25 \mathrm{~km}$ magnetotelluric (MT) profile across the eastern tip of the Acambay graben, oriented approximately perpendicular to the azimuth of the main $\sim \mathrm{E}-\mathrm{W}$ fault systems. The resulting resistivity model incorporates gravity and aeromagnetic coincident model profiles. Density and magnetic susceptibility models were constrained with field sample data, surface geology and with the resistivity structure obtained from the $2 \mathrm{D}$ inversion of the measured MT soundings. The dimensionality and electric strike of the $13 \mathrm{MT}$ stations that compose the profile were analyzed for a period band of 0.01 to $100 \mathrm{~s}$. The average electric azimuth obtained was $88.5^{\circ} \pm 10^{\circ}$, which was used to invert the rotated to the electric strike MT profile. The integrated geophysical model reveals important lithological contrasts at the northern and southern bounding faults of the graben. While the northern Acambay-Tixmadejé fault affects a resistive ground and is associated to a $>20 \mathrm{mGal}$ gravity anomaly, the southern Pastores fault corresponds to a contrasting conductive zone with relatively low gravity anomaly $(\sim 5 \mathrm{mGal})$. In contrast, the magnetic anomaly shows the opposite behavior; at the Pastores fault the observed amplitude is of $400 \mathrm{nT}$ while the amplitude across the Acambay-Tixmadejé fault is insignificant. The geophysical model shows that both the AcambayTixmadejé and Pastores faults have constant and opposite dipping angles of about $70^{\circ}$, defining a nearly symmetric graben structure. According to our results, the Acambay-Tixmadejé fault as well as the central graben fault system converge at a depth of $\sim 18 \mathrm{~km}$ that is consistent with the depth of the seismogenic crustal layer.

Key words: magnetotelluric methods; integrated geophysical data; deep structure; Acambay graben; Mexico.

\section{RESUMEN}

El graben de Acambay es una estructura sísmicamente activa de $\sim 70 \mathrm{~km}$ de longitud en dirección E-O, localizada en la Faja Volcánica Transmexicana (FVTM). El vulcanismo del Cuaternario ha contribuido a modelar la morfología del graben y la actividad hidrotermal reportada sugiere la existencia de potenciales reservorios geotérmicos. Nuestro trabajo tiene como finalidad proveer información acerca de la estructura subsuperficial del graben usando sondeos magnetotelúricos (MT), así como datos gravimétricos y aeromagnéticos, como un trabajo preliminar para un futuro enfoque integral 3D. Analizamos la distribución de las anomalías magnéticas y su relación con el fallamiento usando el campo aeromagnético total (CAT) de las cartas digitales E14 y F14 (https:// $w w w . g o b . m x / s g m$ ) y a través del análisis de la derivada de inclinación del CAT. Las derivadas horizontales de los campos gravitatorio y magnético proporcionaron resultados adicionales para constreñir la localización de la falla principal y para contrastar la respuesta de las fallas Pastores y Acambay-Tixmadejé. Para la interpretación del subsuelo, presentamos el resultado de un perfil magnetotelúrico de $\sim 25 \mathrm{~km}$ que cruza el graben de Acambay en su limite oriental, aproximadamente perpendicular al azimut de los sistemas principales $\sim$ E-O. El modelo de resistividad resultante incorpora modelos de perfiles coincidentes de gravimetría y magnetometría. Los modelos de densidad y la susceptibilidad magnética 
fueron constreñidos con muestras de campo, geología superficial y con la estructura de resistividad obtenida a partir de la inversión $2 D$ de los datos magnetotelúricos medidos. La dimensionalidad y el strike eléctrico de las 13 estaciones magnetotelúricas que componen el perfil fueron analizadas para un ancho de banda de 0.01 a $100 \mathrm{~s}$. El azimut eléctrico promedio obtenido fue de $88.5^{\circ} \pm 10^{\circ}$, el cual fue utilizado para rotar los datos al strike eléctrico e invertir el perfil.

El modelo geofísico integral revela importantes contrastes litológicos en las fallas que limitan el graben al norte y al sur. Mientras que la falla Acambay-Tixmadejé al norte afecta un subsuelo resistivo y está asociada a una anomalía de gravedad $>20 \mathrm{mGal}$, la falla Pastores al sur corresponde a una estructura contrastantemente conductiva con una anomalía de gravedad relativamente pequeña $(\sim 5 \mathrm{mGal})$. En contraste, la anomalía magnética muestra un comportamiento opuesto; en la falla Pastores la amplitud observada es de $400 \mathrm{nT}$, mientras que la amplitud a lo largo de la falla Acambay-Tixmadejé es insignificante. El modelo geofísico muestra que ambas fallas, Acambay-Tixmadejé y Pastores, tienen ángulos de buzamiento constante y opuesto de $70^{\circ}$, definiendo una estructura del graben casi simétrica. De acuerdo con nuestros resultados, la falla Acambay-Tixmadejé, así como el sistema de fallas de la porción central del graben, convergen a una profundidad de $18 \mathrm{~km}$, lo que es consistente con la profundidad de la capa cortical sismogénica.

Palabras clave: método magnetotelúrico; datos geofísicos integrados; estructura profunda; graben de Acambay; México.

\section{INTRODUCTION}

After the 1912 Acambay earthquake, various studies have been performed in order to identify and characterize the seismogenic fault of this graben (e.g., Urbina and Camacho, 1913; Mooser, 1972; Martínez-Reyes and Nieto-Samaniego, 1990; Suter et al., 1992, 1996, 2001). Since the beginning of the 21 st century, various paleoseismological studies have also been carried out in order to evaluate the seismic hazard (Langridge et al., 2000; 2013; Lacan et al., 2013a, 2013b, 2018; Sunye-Puchol et al., 2015; Ortuño et al., 2015, 2018; Velázquez-Bucio and Garduño-Monroy, 2018). In spite of numerous geological studies performed on the Acambay graben to map and study the active faults and volcanic edifices of this region, none was realized so far for imaging structures at depth. Such studies are however necessary to constrain the geometry of the faults at depth and their relations. These parameters are yet determinant to calculate the seismogenic potential of the faults and their cumulative displacement. Moreover, such study could give information about thermal anomalies under the graben related to geothermal circulation and Holocene volcanism. In this paper, we present the first results of an integrated geophysical study using magnetotelluric (MT) soundings, as well as gravity and aeromagnetic data aiming to characterize the deep structure of the Acambay graben.

\section{GEOLOGICAL SETTING}

The Acambay graben is located in the central sector of the TransMexican Volcanic Belt (TMVB) at the intersection between the SSENNW Taxco-San Miguel Allende and the E-W Chapala-Tula faults systems (Figure 1). The Taxco-San Miguel Allende fault system was active from Oligocene to early Pleistocene times (Alaniz-Álvarez et al., 2002). It corresponds to a crustal step between the $50 \mathrm{~km}$ thick crust to the east and the $40 \mathrm{~km}$ thick crust to the west (Ferrari et al., 2012).
The morphological traces of the main faults are well preserved to the north and to the south of the Acambay graben and coincide with numerous hydrothermal sources. In the Acambay graben, the morphological imprint of this fault system was erased by the subsequent activity of the Chapala-Tula fault system but its persistence at depth was revealed by magnetic and gravity anomaly data (De la Fuente and Verma, 1994). The Chapala-Tula fault system is regarded as an active system along the nearly $400 \mathrm{~km}$ of extension of aligned faults. Its central part, the Morelia-Acambay fault system, draws a $\sim 30 \mathrm{~km}$ wide fault belt where WSW-ENE to E-W extensional structures formed tectonic basins (Ferrari et al., 1990; Martínez-Reyes and Nieto-Samaniego, 1990; Pasquarè et al., 1991), being the Acambay graben the easternmost of these basins.

The Acambay graben is an almost east-west striking structure, limited by the Pastores and Venta de Bravo faults to the south, and by the Acambay-Tixmadejé and Epitacio Huerta faults to the north (Figure 2). The graben can be divided into two sub-units. To the west, the graben is wider and $30 \mathrm{~km}$ separates the $50 \mathrm{~km}$ long Venta de Bravo and $32 \mathrm{~km}$ long Epitacio Huerta faults. To the east, the graben is the narrowest and just $13 \mathrm{~km}$ separates the $43 \mathrm{~km}$ long Acambay-Tixmadejé and the $33 \mathrm{~km}$ long Pastores faults (Figure 1). On both of these subunits, inside of the depression, the E-W striking central graben fault system cuts across the graben filling over a distance of $70 \mathrm{~km}$ (Figure 1; Martínez-Reyes and Nieto-Samaniego, 1990; Johnson and Harrison 1990; Suter et al., 1992, 1995).

Since the beginning of its opening during Miocene time, the Acambay graben has been filled by a series of volcanic deposits and fluvial-lacustrine sediments that in some places are overlapped by volcanic edifices and lava flows. The $1912 \mathrm{Mw} 6.9$ Acambay earthquake, associated with surface ruptures along Acambay-Tixmadejé, Pastores and Temascalcingo fault systems, highlighted the Holocene activity of the northern border of the graben. This persistent tectonic activity has been then demonstrated for most of the graben faults by different paleoseismological studies (Langridge et al., 2000; 2013; Lacan et al., 2013a, 2013b, 2018; Ortuño et al., 2015; Sunye-Puchol et al., 2015). The relation between tectonic activity and volcanism is not clear within the graben. Some volcanic edifices appear to be aligned along active faults but are also cut by the faults. This could indicate a contemporaneity between tectonic activity and volcanism that could persist into the Holocene as indicated by the volcanic deposits encountered in paleoseismological trenches (Aguirre-Díaz et al., 2015).

\section{MAGNETIC DISTRIBUTION AND FAULT STRUCTURES ALONG THE ACAMBAY GRABEN}

High quality aeromagnetic data covering the country at scale 1:50,000 have been readily available in Mexico for more than two decades. Although this scale may not be convenient for detailed prospection purposes, it is quite useful to assess the structure of large tectonic features such as the Acambay graben. Figure 3a shows the Residual of the Total Magnetic Field (RTMF) anomaly chart of the Acambay graben area, obtained from the combination of the processed digital aeromagnetic charts E14 and F14 (https://www.gob.mx/sgm). The magnetic data were acquired by the Consejo de Recursos Minerales (CRM), now Servicio Geológico Mexicano (SGM), using a high sensitivity ( $>0.01 \mathrm{nT}$ ) Cesium magnetometer at a constant height of $300 \mathrm{~m}$ above terrain topography and have been corrected for diurnal variations and referenced to the IGRF (e.g., Lowrie, 2007). Blue tones in the figure represent low magnetization zones whereas red tones characterize high magnitudes of magnetization, yellow-green colors are inflexion zones where the horizontal gradients reach maximum values. For comparison 


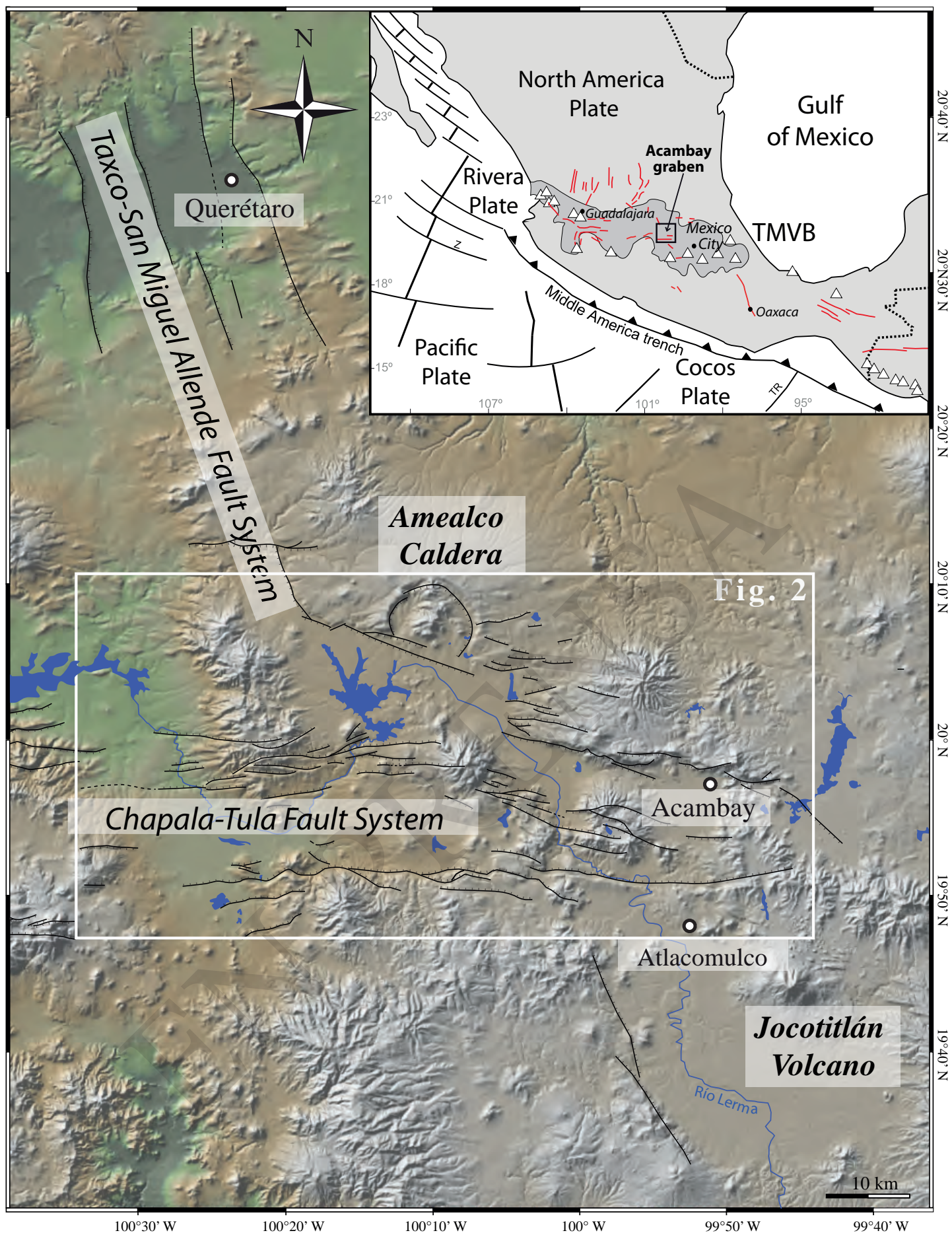

Figure 1. Geomorpho-structural map of the Acambay graben intersecting the Taxco-San Miguel Allende fault system. Inset shows the location of the study area in the Trans-Mexican Volcanic Belt (TMVB). TR: Tehuantepec ridge.

we have included the main fault traces (black lines), the course of the Lerma River (blue line), and volcanic edifices (red triangles) in the figure (Lacan et al., 2013a). The thick dashed line in the right side of the figure represents the trace of coincident MT and ground gravity profiles, and the thinner dashed line shows the trace of the western ground gravity profile. We applied the reduction to pole and horizontal gradients procedures to the data, and estimated the tilt magnetic chart
(Miller and Singh, 1994); however, the later fitted better the surface faults. Figure $3 \mathrm{~b}$ shows the tilt of the RTMF, which emphasizes lateral variations in magnetization through the ratio between the vertical and total horizontal field gradients (Verduzco et al., 2004). The eastern side of this chart shows nearly E-W lineaments, whereas the western side shows a less obvious trending pattern. Mapped fault traces are only partly coincident with maxima or minima of the RTMF or tilt align- 


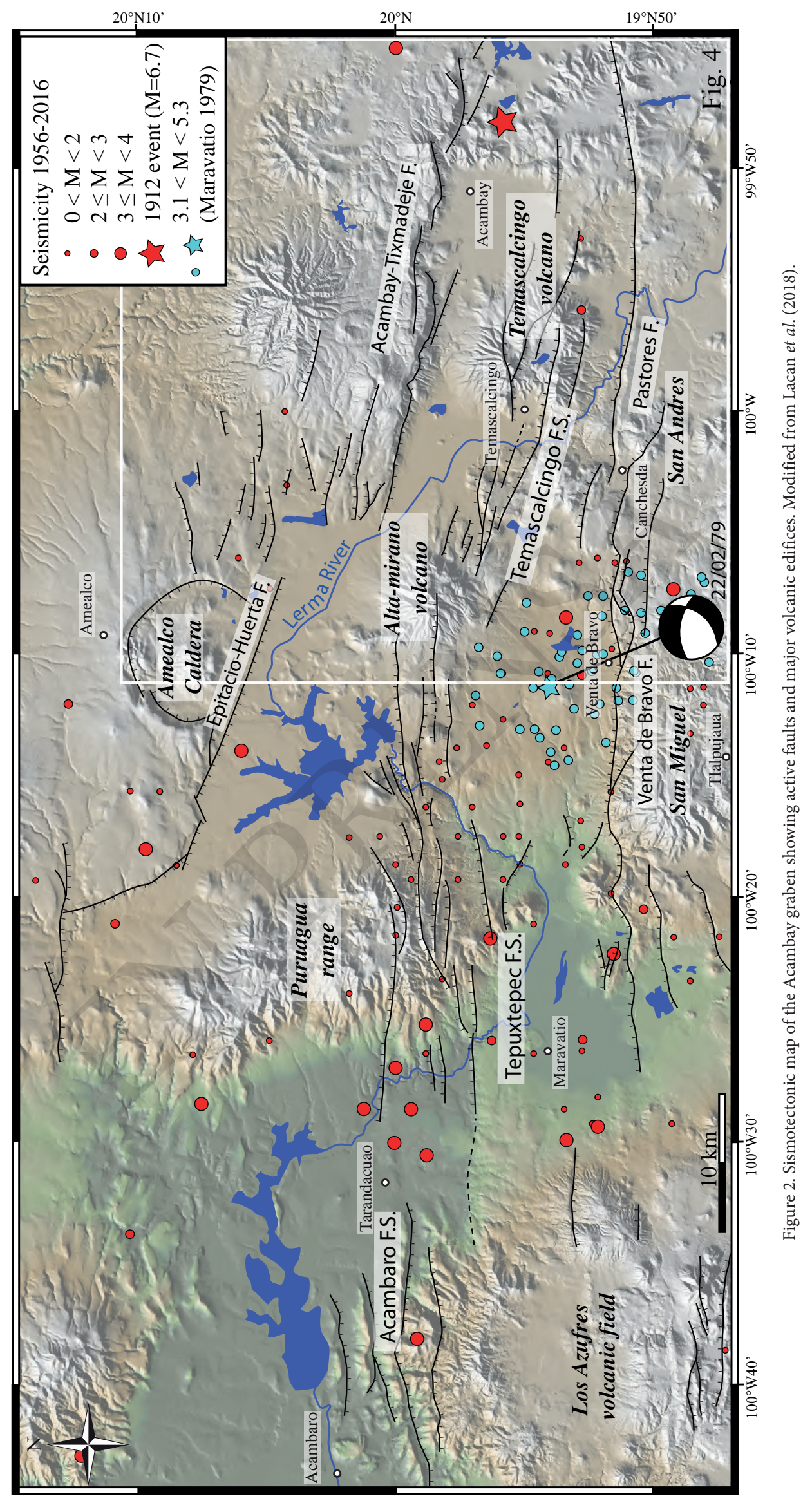




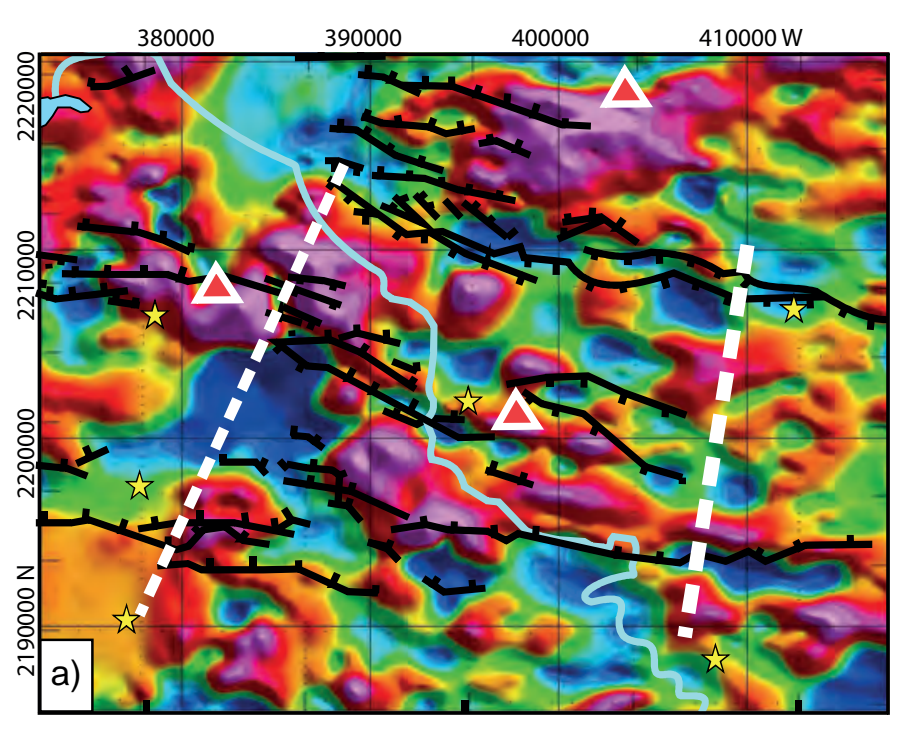

$\mathrm{nT}$
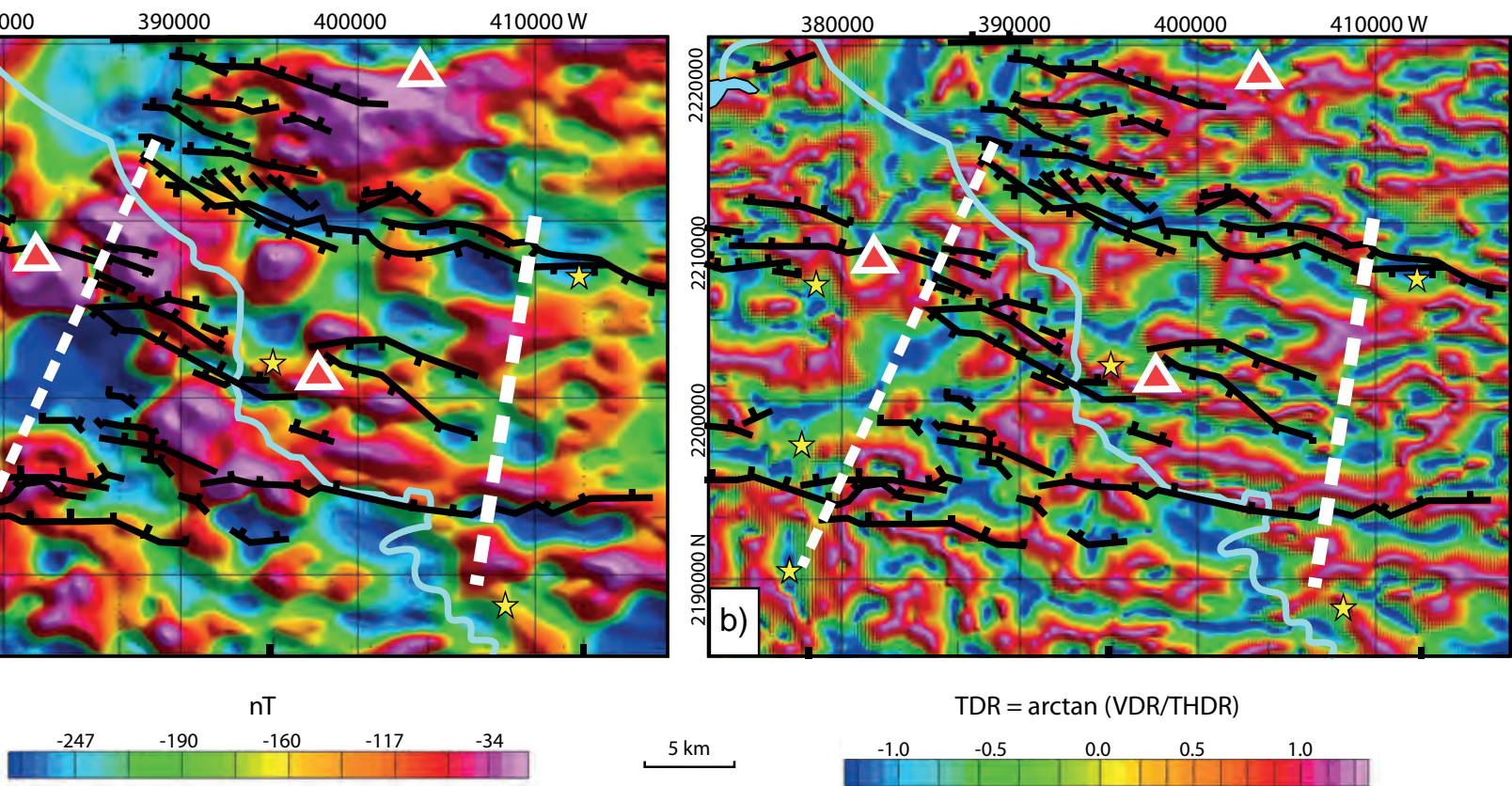

$\mathrm{TDR}=\arctan (\mathrm{VDR} / \mathrm{THDR})$

$5 \mathrm{~km}$

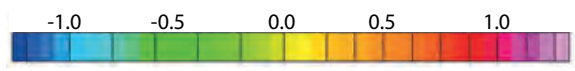

Figure 3. a) Residual of the total magnetic field (RTMF) chart of the Acambay graben; b) Tilt chart of the RTMF for the same area. Fault traces are from Lacan $e t$ al. (2013a), triangles represent volcanic edifices, stars cities and towns, pale blue line across the graben represents the Lerma river, the thin dashed line is a ground gravity profile and the thick dashed line is the interpreted magnetotelluric, and coincident gravity and magnetic profiles. TDR: Tilt Derivative of the RTMF; Vertical Derivative of the RTMF; THDR: Total Horizontal Derivative of the RTMF.

ments, indicating that fault traces on surface not always are represented by a magnetic alignment response.

However, the Pastores fault trace appears to be closely related to the elongated magnetic anomaly observed in the southeastern sector of the Acambay graben. Elsewhere in the graben area, the spatial relation between the main faults and the magnetic alignments observed is not obvious. Indeed, the magnetic signature is portraying a complex graben structure at depth where volcanic edifices play an important role in the distribution of magnetized ground. Furthermore, not only ferromagnetic minerals dispersed within the host rocks matrix of the volcanoes surroundings account for the observed high magnetic anomalies as large as $400 \mathrm{nT}$, but also trapped differentiated ensambles of magnetic minerals above the Curie point from nearby volcanic centers may contribute importantly to the surface magnetic signature (Arzate et al., 2017).

\section{THE MAGNETOTELLURIC DATA SET AND GRAVITY PROFILES}

The magnetotelluric survey comprised the measurement of 13 magnetotelluric (MT) soundings along a $25 \mathrm{~km}$ nearly NS transect across the Acambay graben, as well as of 12 time-domain (TDEM) single loop shallow soundings used to correct the MT resistivity data for static shift. We also collected data at a total of 83 gravity stations along two nearly parallel profiles, one of which is coincident with the MT resistivity transect. Figure 4 shows the location of the MT stations, the TDEM sounding sites, and the ground gravity stations.

We used Phoenix MTU-2000 and V8 systems for the MT soundings and terraTem equipment for the complementary TDEM soundings. In addition, four long period magnetotelluric (LMT) stations were installed using four LEMI-417 stations evenly distributed along the profile measuring simultaneously for one week, aimed to improve data quality at longer periods ( 100 s). The MT stations registered during periods of 10 to 18 hours. The effective frequency band used for interpretation was 1000 to $0.01 \mathrm{~Hz}$, which represents a maximum investigation depth (skin depth) range between $\sim 100 \mathrm{~m}$ and $50 \mathrm{~km}$, assuming a bulk resistivity value of $100 \mathrm{ohm} \cdot \mathrm{m}$. Investigation depth increases by one order of magnitude at those sites where we used broadband (MT + LMT) soundings. However, we focus on the distribution of the electrical resistivity in the depth range from surface to a maximum of $10 \mathrm{~km}$. MT and LMT data were processed separately using Phoenix and LEMI's software respectively. Both processing procedures provided electronic data interchange (EDI) standard format plots that can be easily combined.

The resistivity and phase sounding curves, defined by $\rho_{i j}(\omega)=$ $\left(1 / \omega \mu_{0}\right)\left|Z_{i j}(\omega)\right|^{2}$ and $\phi_{i j}=\tan ^{-1}\left[\operatorname{Im} Z_{i j}(\omega) / \operatorname{Re} Z_{i j}(\omega)\right]$, respectively, where $\omega$ is equal to $2 \pi \mathrm{f}$, and $i$, and $j$ are the off-diagonal elements $Z_{x y}$ or $Z_{y x}$ of the impedance tensor, are shown in Figure 5. These static-shift corrected data, measured in a NS-EW reference coordinate system, are the basis of the MT interpretation of the ground in terms of the variations of conductivity with depth. The electric azimuth deduced from the impedance tensor is regarded as a proxy for geological contacts either near-surface or at depth, as penetration depth is frequency dependent. We used Weaver et al. (2000) impedance phase approach to estimate the electric strike $\phi$ at the 40 discrete frequencies measured at the 13 MT stations along the profile.

The detailed analysis of the electric azimuth $\phi$ provides a mean to trace variations of geological structures as a function of depth and position, particularly when structures are good electric conductors or a conductivity contrast prevails across them. Figure 6 shows the electric strike azimuth plotted along the MT profile for three selected period bands: $\mathrm{t}<1 \mathrm{~s}, 1<\mathrm{t}<10 \mathrm{~s}$, and $\mathrm{t}>10 \mathrm{~s}$ (or equivalent frequency $f<1 \mathrm{~Hz}, 1<f<10 \mathrm{~Hz}$, and $f>10 \mathrm{~Hz}$ ), corresponding to skin depths of $<5 \mathrm{~km}$, between 5 and $15 \mathrm{~km}$ and $>15 \mathrm{~km}$, respectively, assuming the same bulk ground resistivity of $100 \mathrm{ohm} \cdot \mathrm{m}$ as above. The calculated 
strike azimuths as function of frequency are indicated with red lines within the white circles for the corresponding MT stations. Electric strike azimuth is somewhat scattered at high frequencies, although at intermediate and lower frequencies appear more consistent with the graben E-W regional fault system, except at some sites due to local distortion.

Scattering of electric strike at shallow depths (Figure 6a) may be an indication of two or more fault systems prevailing within the upper $5 \mathrm{~km}$ of the crust. At skin depths ranging between 5 and $15 \mathrm{~km}$ (Figure 6b), the electric azimuth is more consistent, but differences still prevail between the southern and northern strikes azimuths, yielding more scattered results towards the southern Pastores fault structure. At skin depths below $15 \mathrm{~km}$ down to about $50 \mathrm{~km}$ (Figure 6c) the electric azimuth is scattered again although some sites within the graben structure still show the influence of the E-W fault system. The average electric azimuth estimated for the full frequency band yields $88.5^{\circ} \pm 10^{\circ}$, which is well consistent with the $\sim \mathrm{E}-\mathrm{W}$ geological strike of the graben structure in the eastern region.

\section{THE MT RESISTIVITY 2D SECTION}

We modeled the MT data using the nonlinear conjugate gradient algorithm of Rodi and Mackie (2001) for two-dimensional inversion. The nearly E-W geologic strike of the graben fault system is consistent with the average electric azimuth $\left(88.5^{\circ}\right)$ obtained and used to rotate the impedance tensor. In this reference frame, the transverse electric (TE) and transverse magnetic (TM) polarization modes are defined

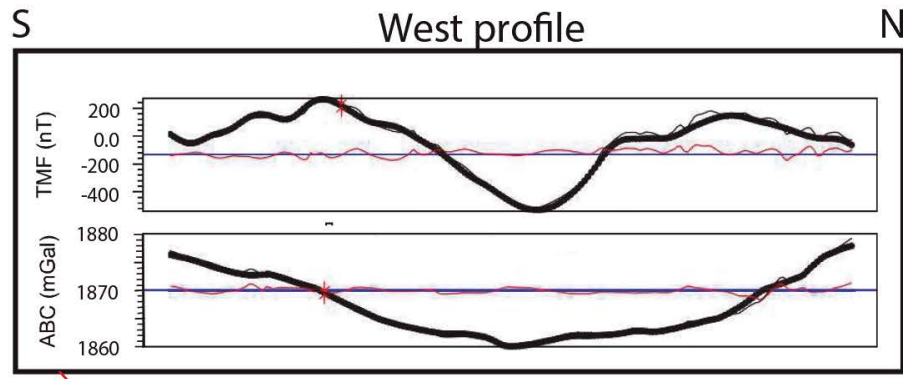

$\mathrm{S}$

East profile $\mathrm{N}$

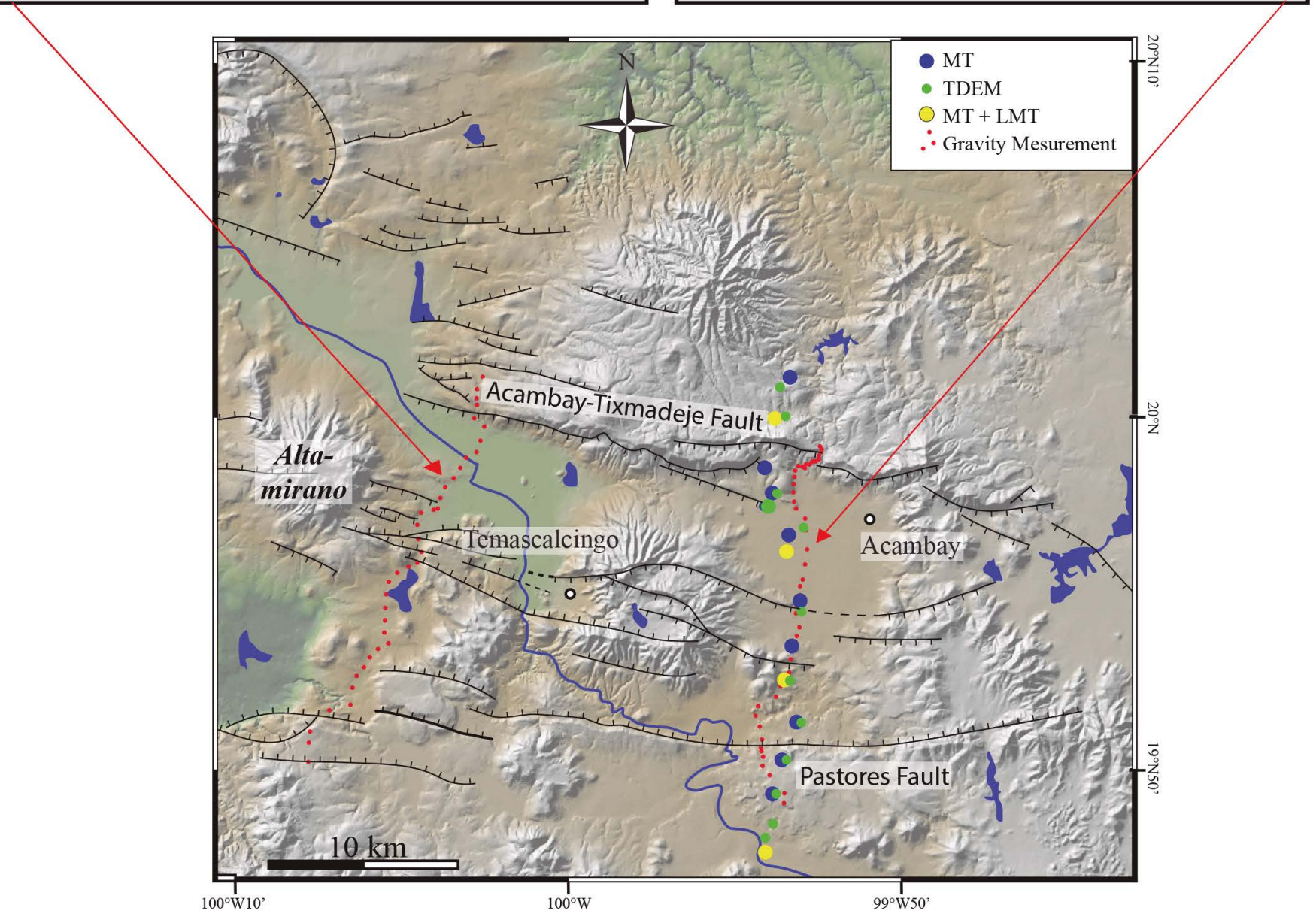

Figure 4. Location of magnetotelluric (MT) and long period magnetotelluric (LMT) soundings (blue and yellow circles), sites of time-domain electromagnetic (TDEM) soundings (green circles), and gravity stations (red dots) across the Acambay graben. The upper graphs show the total magnetic field (TMF) extracted from the digital magnetic charts (see text) and the terrain corrected interpolated Bouguer Anomaly (ABC) for the western (left) and eastern (right) geophysical profiles across the graben structure. 
across and parallel to the graben structure, respectively. Before the simultaneous inversion of the TE and TM modes we tested the grid size and the effect of the smoothness/rugosity parameter $\tau$ for values from 0.1 to 10 being completely smoothed at the later. The optimal factor of $\tau=0.95$ was used for the final inversion with 40 iterations, after which the root mean square (RMS) misfit did not diminished, reaching a minimum RMS misfit equal to 2.15 (Figure 7). The resulting resistivity image along the MT profile down to $35 \mathrm{~km}$ depth is shown in Figure 7 . High conductivity anomalies $(1-50 \mathrm{ohm} \cdot \mathrm{m})$ are concentrated close to the surface and at the southern end of the profile, suggesting a northward dipping contact at depth (continuous black line) with a relatively resistive $(\sim 1000 \mathrm{ohm} \cdot \mathrm{m})$ regional basement.

The southern $\sim 70^{\circ}$ dipping contact zone corresponds to the trace of the Pastores fault, whereas the Acambay-Tixmadejé fault, with an
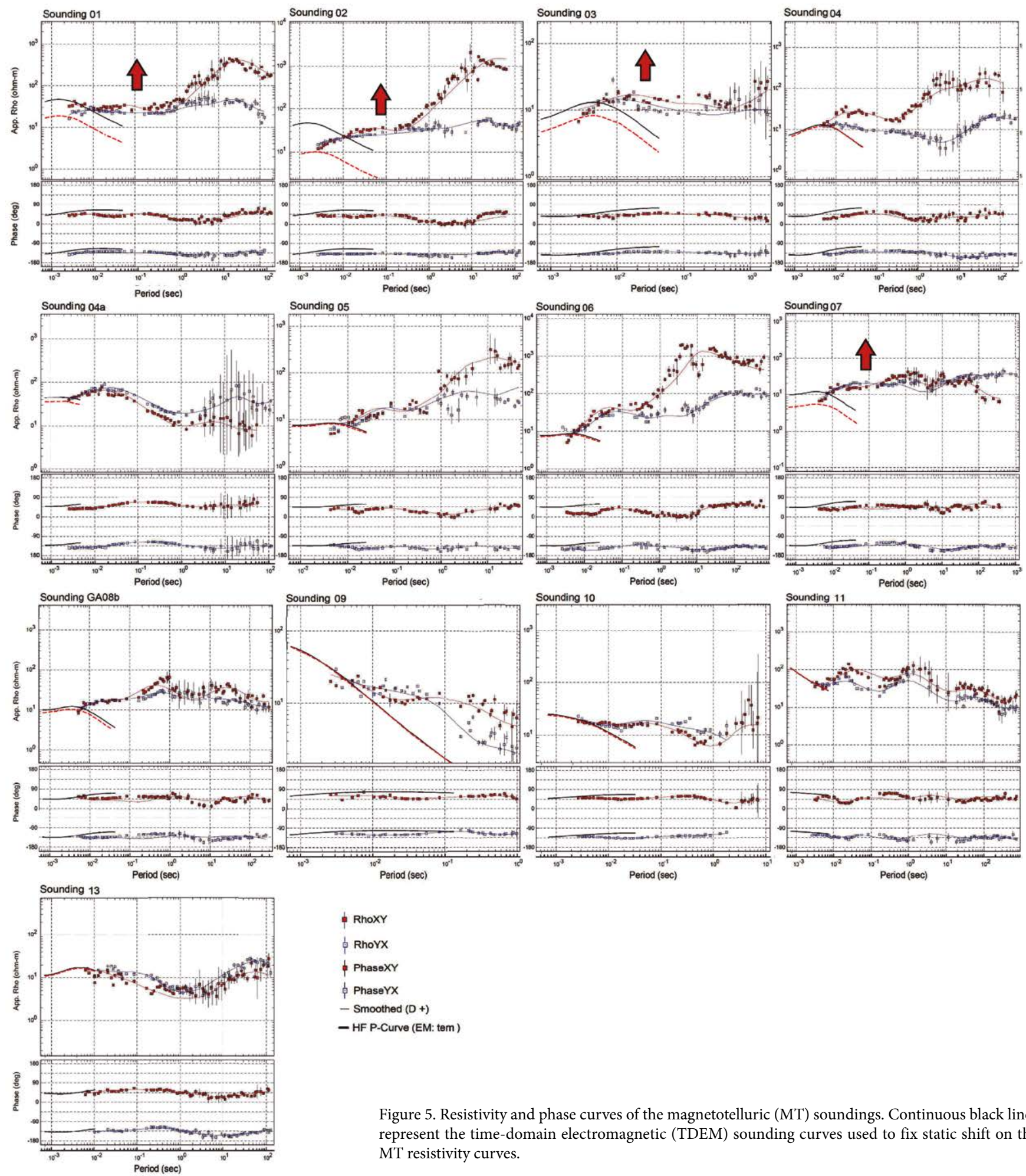

Figure 5. Resistivity and phase curves of the magnetotelluric (MT) soundings. Continuous black lines represent the time-domain electromagnetic (TDEM) sounding curves used to fix static shift on the MT resistivity curves. 
estimated dipping angle of nearly $70^{\circ}$ as well (thinner southwards dipping black line), appears to occur within the same basal unit. The resistive basement defines two sub basins, one in the northern part of the profile and the other in the central part, of about 1 and $2 \mathrm{~km}$ thickness, respectively. Other resistive zones are shown as isolated patches near the surface above $\sim 2 \mathrm{~km}$, which are the responses of near surface volcanic products that are shown dissociated perhaps because of the limited sounding coverage. The conductive-resistive inclined contact parallel to the trace of the Pastores fault is well constrained by most of the MT sites along profile, however the western fault contact is more ambiguous and could have variations to lower values.

\section{DISCUSSION: STRUCTURE OF THE EASTERN ACAMBAY GRABEN}

The upper crustal resistivity in the Acambay graben varies from low to intermediate values $(200-1000 \mathrm{ohm} \cdot \mathrm{m})$ in contrast with upper crustal resistivities observed in western and south-western Mexico (Corbo et al., 2013, Arzate et al., 2017), where "normal" crustal values are consistently above several thousand $\mathrm{ohm} \cdot \mathrm{m}$. Furthermore, in the surroundings of Pastores fault and southwards, the crust becomes still less resistive reaching abnormally low values $(<200 \mathrm{ohm} \cdot \mathrm{m})$, perhaps as result of metasomatic processes, actual or ancient. Figure 8 provides a general perspective at a shallower scale of the resistivity structure in comparison with the surface trace of the main fault systems. The spatial distribution of the resistivity suggests that not only the Pastores fault is affected by anomalous conductivities but also the fault system lying inside the graben structure. This interpretation implies a geologic contact of regional character apparently related to the volcanic front of the TMVB and influenced by the southwards dipping fault system.

Figure 9a shows the interpreted resistivity section in terms of conductivity changes of the structure in the eastern sector of Acambay graben, constrained with surface geology and confined below surface by the interpolated faults. Both normal faults bounding the graben present a dipping angle close to $70^{\circ}$, converging at a crustal depth of
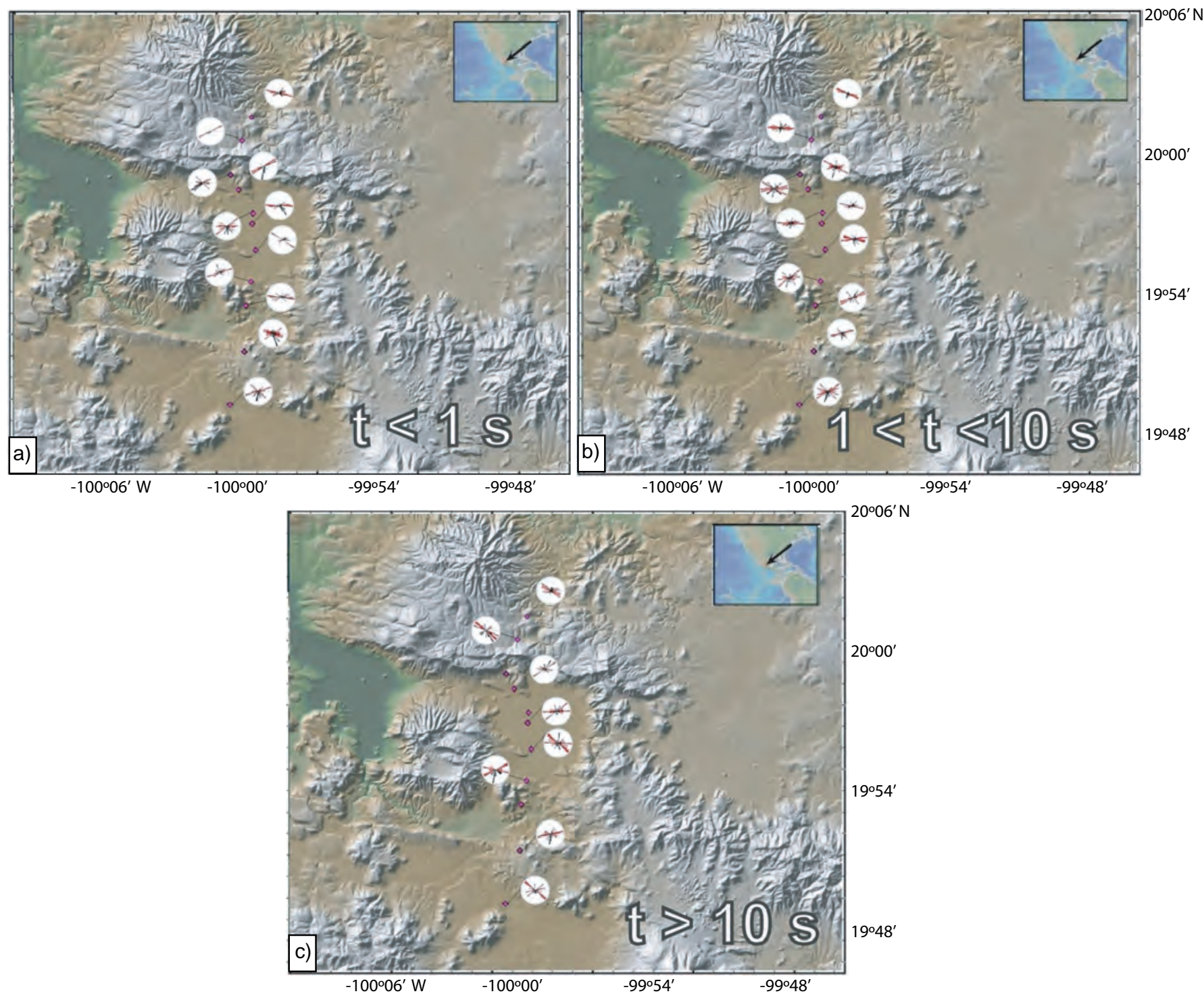

Figure 6. Electric strike (red lines within the circles) and tipper strike and magnitude (black lines within the circles) for the period bands of $\mathrm{t}<1 \mathrm{~s}$ (a), $1<\mathrm{t}<10 \mathrm{~s}$ (b), and t $>10 \mathrm{~s}$ (c). Every circle corresponds to a MT station (red dots). 
$\sim 18 \mathrm{~km}$ (Figure 7), which lie within the seismogenic crustal depth range estimated by Rodríguez-Pérez et al. (2017) for the region (i.e., $15-20 \mathrm{~km})$.

Since the 1912 Acambay earthquake, the Acambay-Tixmadejé fault, which presented the most important co-seismic displacement, has been considered intuitively as the main fault of the graben. Here we show that the $80 \mathrm{~km}$ long Pastores-Venta de Bravo fault system that forms the southern graben border could be the main fault of the graben. In this case, the Acambay-Tixmadeje fault is acting as an antithetic fault. This geometry at depth of the Acambay graben faults could explain why the Acambay earthquake ruptured not only along the Acambay-Tixmadejé fault but also along the Pastores fault and along the central graben fault system. Such geometry is important to evaluate the possibility of multiple fault ruptures in the Acambay graben and the possibility of generating major earthquakes.

Although lateral resolution is limited by the MT sounding density, the vertical ground structure is well constrained by the high number (80) of measured frequencies, which helps to distinguish contrasting conductivity layering (dashed lines in Figure 9a). We used this stratified structure to model the density structure assuming that resistive bodies are denser than the conductive ground and using field samples as reference density values. Densities at increasing depths were adjusted accordingly; however the lack of a regional gravity field in the data suggests that the measured gravity anomaly along the profile is mainly due to the upper 3-4 $\mathrm{km}$.

The gravity and magnetic anomalies (Figures $9 \mathrm{~d}$ and 9c) have a contrasting behavior across the Acambay-Tixmadejé fault with respect to the Pastores fault system. To the north, the gravity anomaly ( $\sim 20 \mathrm{mGal}$ ) (Figure 9d) suggests an important vertical displacement at depth across the fault trace, whereas across the southern Pastores fault there is no significant gravity anomaly, which indicates a low lateral density contrast across the fault contact. In contrast, the magnetic anomaly across Pastores fault is quite important ( $400 \mathrm{nT}$ peak to peak) whereas its magnitude across the northern fault system is almost insignificant. The dotted red ellipses in Figure $9 \mathrm{~b}$ represent zones of higher magnetization that together roughly reproduce the residual of the magnetic anomaly. According to these results, magnetized zones in the southern fault system appear to be related to contact zones where resistivity values lie below $200 \mathrm{ohm} \cdot \mathrm{m}$ that can be explained in terms of magnetic metasomatism.

The results suggest different physical conditions at either fault contacts. The northern fault occurs within the same basement unit, which is supported by the resistivity structure and the type of gravity anomaly observed across the fault, while the southern fault come out to be the contact between two equally dense basements units but with different electrical properties across the contact. We speculate that the Pastores fault and the fault system within the graben act as a permeable layer between the southern hydrated-altered basement and the more resistive basement rocks that extent northwards. The observed magnetic high anomaly across the fault enhances the different electrical character of the basements that become polarized close to the fault plane surface and within the graben structure; polarization could be
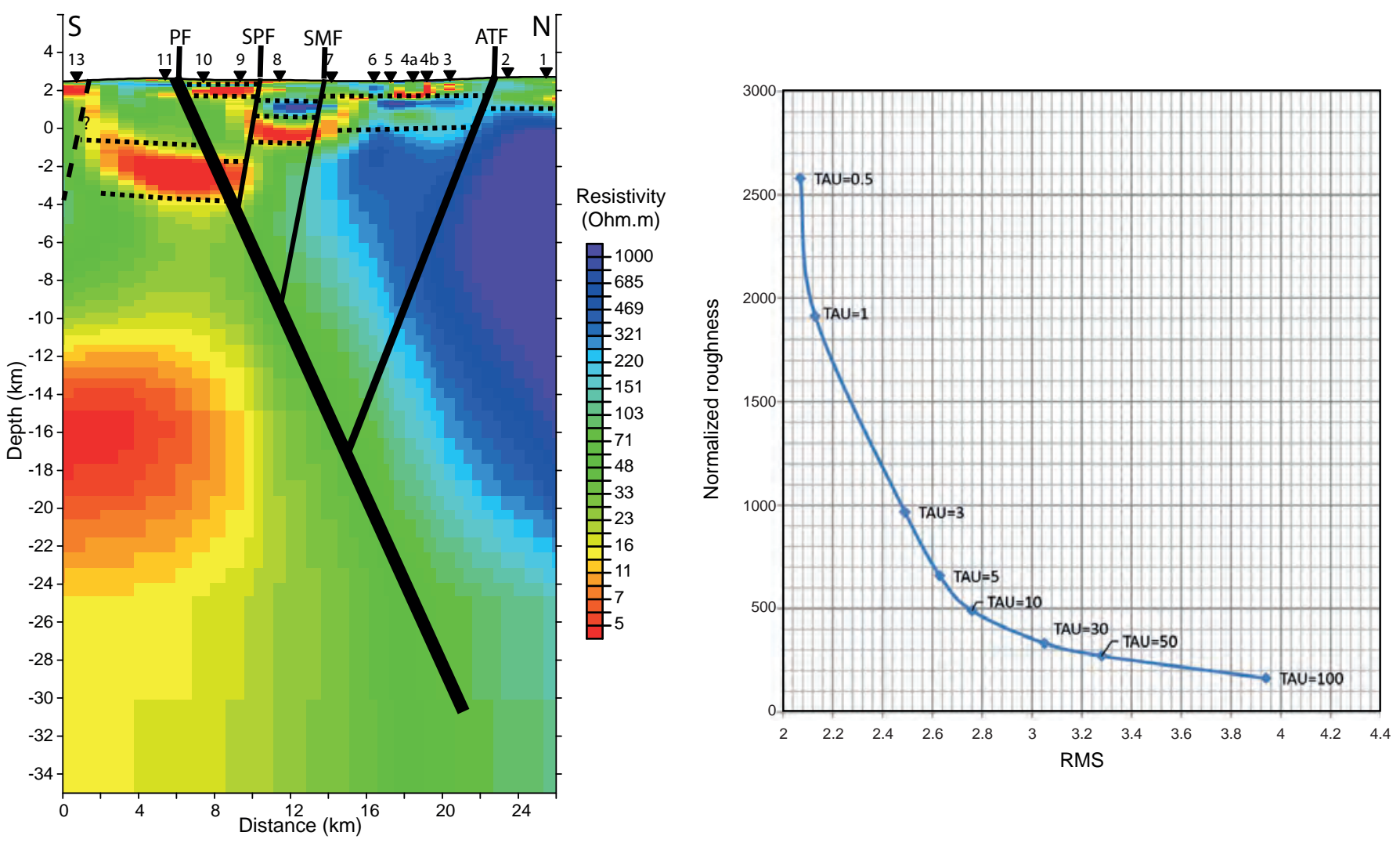

Figure 7. Resistivity section obtained from 2D modeling of the magnetotelluric soundings across the graben structure. Red and yellow tones represent the anomalous conductive zones, whereas the magenta and blue tones are associated with resistive lithology. Fault traces (solid lines) were extrapolated from their surface trace to depths suggested by resistivity contrasts between geologic units. The Pastores fault (PF), San Pedro Fault (SPF), San Mateo Fault (SMF), and Acambay-Tixmadejé fault (ATF) converge in the first $\sim 18 \mathrm{~km}$ depth. Inverted triangles are the location of the MT stations. In the right graph, the rugosity and root mean square (RMS) misfit values are plotted as a function of parameter tau $(\tau)$. A value of $\tau=1$ was used to avoid too rugged or too smoothed results. Dotted lines represent limits of layers with contrasting conductivities. 
generated by mineralized imprint due to propylitic metasomatism in the surroundings of active or recent volcanism. The presence of nearby Temascalcingo and Jocotitlán volcanoes within and south of the graben, respectively, appear to play a significant role for the conductive ground around the Pastores fault as well as for the observed magnetic signature.

\section{CONCLUSIONS}

This geophysical study is the first attempt to image the crustal structure of the Acambay graben. Previously unknown features of the internal structure of the graben where found by the combination of three geophysical methods: magnetotelluric soundings, gravimetry and magnetometry as well as surface geology.

The results provide new insights to understand the geometry and relation between faults affecting this active tectonic region. The geophysical model shows that Acambay-Tixmadejé and Pastores faults have opposite dipping angles of about $70^{\circ}$, defining a nearly symmetric graben structure. The conductive-resistive inclined contact parallel to the trace of the Pastores fault is better constrained by most of the MT sites along profile than the northern fault contact, which is more diffuse and could have variation to lower values. According to the resistivity model, the important conductivity contrast associated to the
Pastores fault may indicate that this fault zone is driving the tectonic extensional process in the area. However, further evidence is required to confirm this hypothesis, which may come from additional MT surveying.

According to our results, the Acambay-Tixmadejé fault, as well as the central graben fault system, converges with the Pastores fault within the first $\sim 18 \mathrm{~km}$ of the crust, which is consistent with the depth of the seismogenic crustal layer. Such geometry represents an important result for evaluating the possibility of occurrence of earthquakes rupturing along various faults of the graben as observed for the 1912 earthquake. We argue that the connection of faults at depth explains why the surface rupture associated with the 1912 event occurred on several faults despite being separated by about ten kilometers.

The crustal resistivity in the Acambay graben zone exhibits an anomalous conductivity as compared with upper crustal resistivities observed in western and south-western Mexico, where "normal" crustal values are consistently above several thousand $\mathrm{ohm} \cdot \mathrm{m}$. In particular, in the neighbourhood of the Pastores fault and southwards, the crust becomes more conductive reaching abnormally low values ( $<200 \mathrm{ohm} \cdot \mathrm{m})$, perhaps as a result of ongoing metasomatic processes within a hydrated matrix, triggered by the proximity of the Temascalcingo and Jocotitlán volcanoes. The existence of geothermal alteration within the eastern Acambay graben structure is further evidence of the geothermal potential of the zone as an energy source, yet to be prospected.

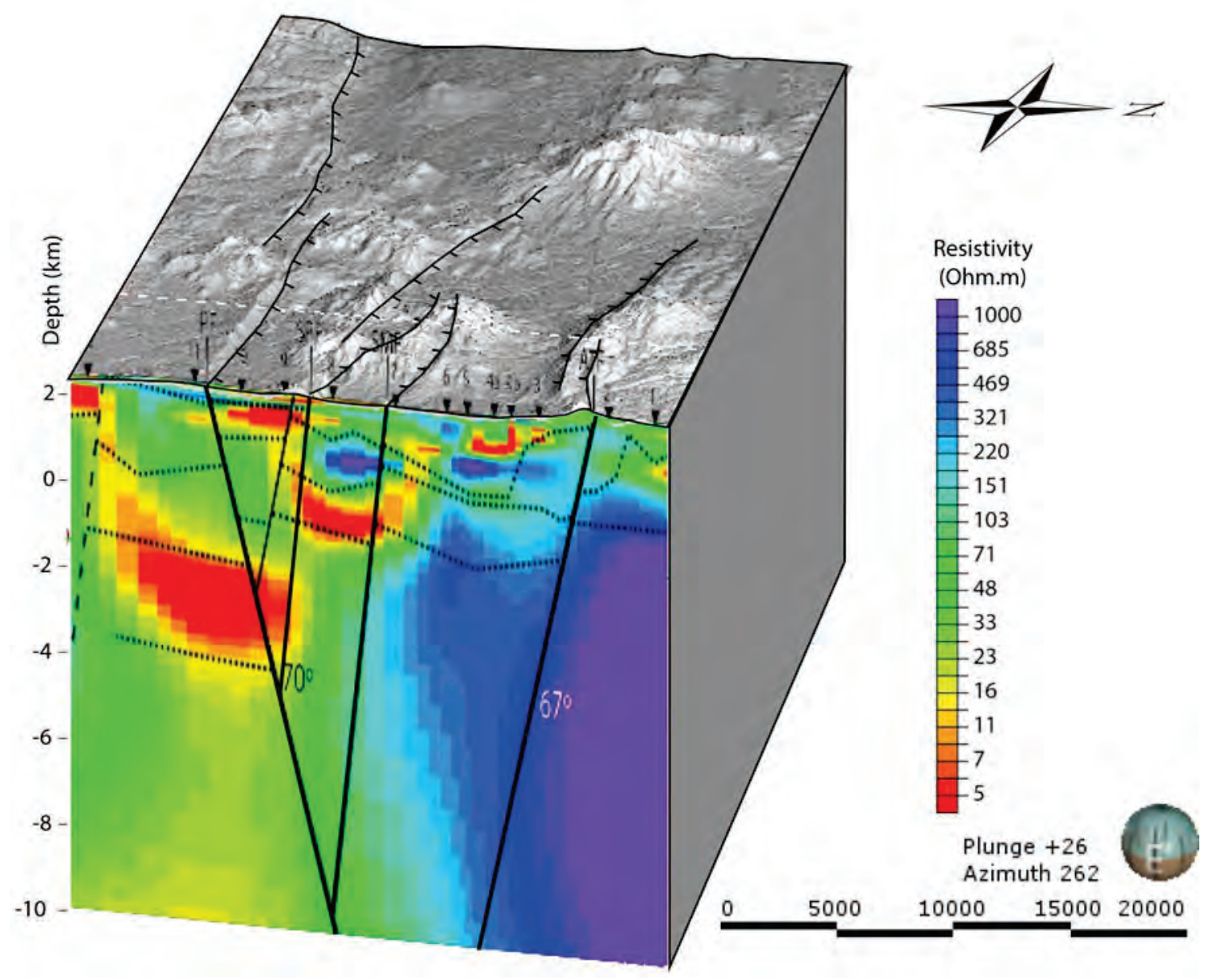

Figure 8. Regional view of the resistivity structure in comparison with the fault systems that conform the Acambay graben. The upper crust in the southern limit of the graben is abnormally conductive. The graben structure in this sector can be regarded symmetric as the estimated angles for the south and north faults are within the measurement errors $\left(\sim 70^{\circ}\right.$ and $\sim 67^{\circ}$ respectively). 


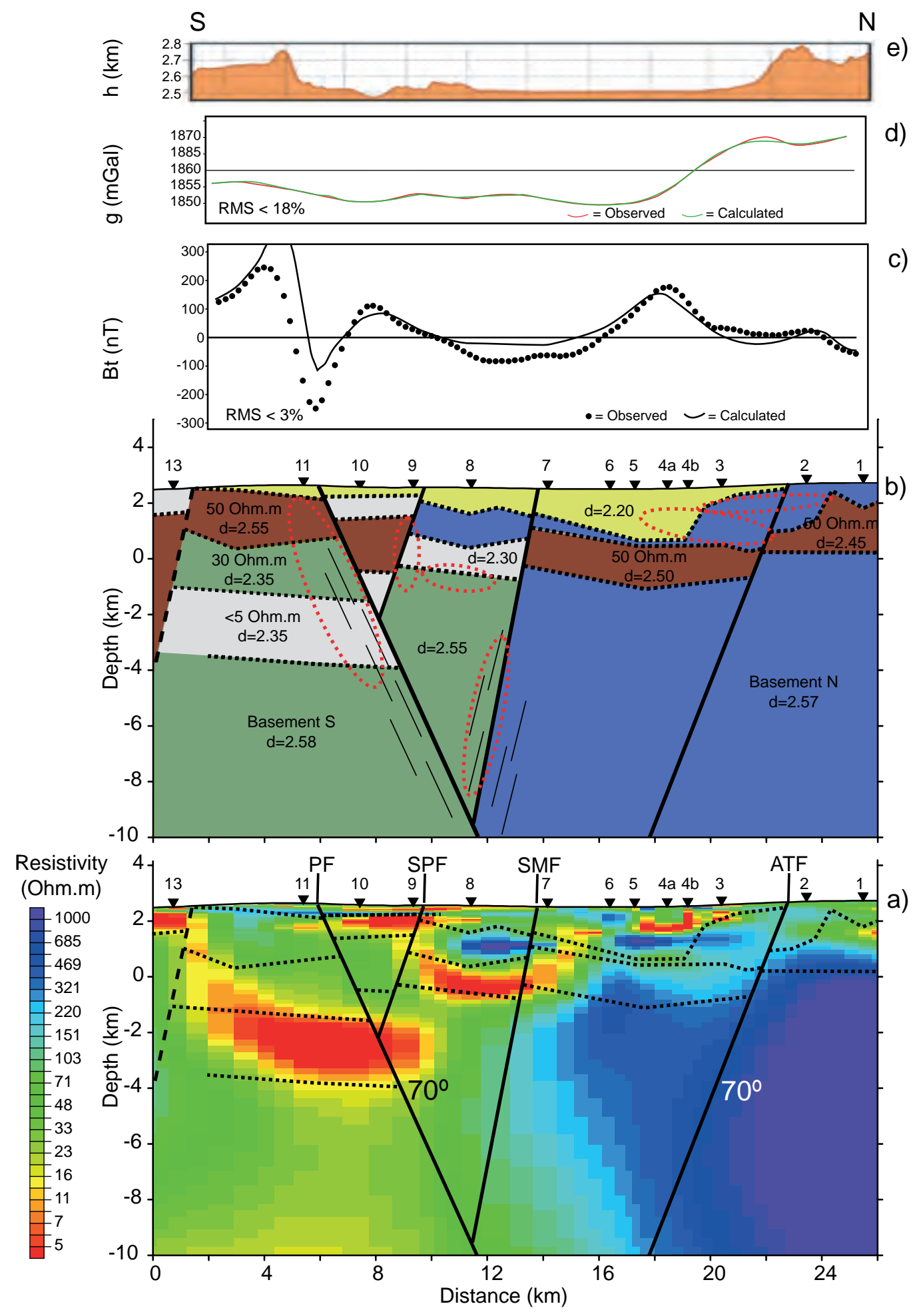

Figure 9. Resistivity section from the simultaneous inversion of the two polarization modes (a) with faults extrapolated from surface locations (continuous black lines) and interpreted contrasting conductivity layering (dashed lines). The synthetized resistivity structure (b) was the base for the 2D density model obtained from the complete Bouguer anomaly using WingLink' software, which is based upon a Talwani et al. (1959) subroutine. The model was constrained with data (density and magnetic susceptibility) from lab measurements of rocks from surface sampling (Felix-Maldonado, 2017). Dashed ellipses in (b) are dipolar bodies necessary to reproduce the residual of the reduced to pole magnetic field. Magnetic susceptibilities contrasts as large as $10^{3}$ emu are required to reproduce the amplitude of the magnetic anomalies along the profile. These magnetized bodies are correlated with fault traces or stratified contacts (zones marked with parallel lines). At the top of the figure, the enhanced topography profile is shown (e). (c) and (d) show the fitted total magnetic field and Bouger anomalies, respectively. Surface fault traces, correlated with contrasting conductivity alignments at depth, fit the density model and can be reproduced as vertical displacements of the interpreted subsurface lithology. The volcano sedimentary filling of the graben has an estimated maximum thickness of $\sim 2 \mathrm{~km}$. 


\section{ACKNOWLEDGMENTS}

The authors are grateful with Andrés Arzate, Gonzalo Romero, Diego Ruiz, and Gabriela Vera who participated in the fieldwork campaigns. This work was supported by the Universidad Nacional Autónoma de México [DGAPA-PAPIIT grants IA101615, IA102317 and IN116816]. Leapfrog-geo and winGLink academic licenses were used for analyzing and modeling.

\section{REFERENCES}

Aguirre-Díaz, G.J., Pedrazzi, D., Lacan, P., Roldan-Quintana, J., Ortuño, M., Zúñiga, R., Audin, L., and Acambay Graben Team 2015, , Quaternary volcanism in the Acambay Graben, Mexican Volcanic Belt: Re-evaluation for potential volcanic danger in central Mexico, in AGU Fall Meeting: San Francisco, CA, USA, American Geophysical Union, abstract V31B-3029.

Alaniz-Álvarez, S.A., Nieto-Samaniego, A.F., Morán-Zenteno, D.J., AlbaAldave, L., 2002, Rhyolitic volcanism in extension zone associated with strike-slip tectonics in the Taxco region, southern Mexico: Journal of Volcanology and Geothermal Research, 118(1-2), 1-14, doi:10.1016/ S0377-0273(02)00247-0.

Arzate, J.A., Corbo-Camargo, F., Carrasco G., Hernández, J., Yutsis, V., 2017, The Los Humeros (Mexico) geothermal field model deduced from new geophysical and geological data: Geothermics, 71, 200-211.

Corbo-Camargo, F., Arzate-Flores, J.A., Álvarez-Béjar, R., Aranda-Gómez, J.J., Yutsis, V., 2013, Subduction of the Rivera plate beneath the Jalisco block as imaged by magnetotelluric data: Revista Mexicana de Ciencias Geológicas, 30(2), 268-281.

De la Fuente, G.J., Verma, S.P., 1994, Catálogo de aparatos volcánicos de la parte centro-occidental del Cinturón Volcánico Mexicano: Geofísica Internacional, 32, 351-386.

Ferrari, L., Pasquarè, G., Tibaldi, A., 1990, Plio-Quaternary tectonics of the central Mexican Volcanic Belt and some constraints on its rifting mode: Geofísica Internacional, 29(1), 5-18.

Ferrari, L., Orozco-Esquivel, T., Manea, V., Manea, M., 2012, The dynamic history of the Trans-Mexican Volcanic Belt and the Mexico subduction zone: Tectonophysics, 522-523, 122-149.

Johnson, C.A., Harrison, C.G.A., 1990, Neotectonics in central Mexico: Physics of the Earth and Planetary Interiors, 64, 187-210.

Lacan, P., Zúñiga, F.R., Ortuño, M., Persaud, M., Aguirre-Díaz, G.J., Langridge, R.M., Villamor, P., Perea, H., Štěpančíkov., P., Carreón, D., Cerca, M., Suñe Puchol, I., Corominas, O., Audin, L., Baize, S. Lawton, T.F., Rendon A., 2013a, Paleoseismological history of the Acambay Graben (central Mexico): Eos, Transactions, American Geophysical Union, 94, T23C-2591.

Lacan, P., Ortuño, M., Perea, H., Baize, S., Audin, L., Aguirre, G., Zúñiga, F.R., 2013b, Upper Pleistocene to Holocene earthquakes recorded at the western termination of the Venta de Bravo fault system, Acambay Graben (central Mexico), in Grützner, C., Rudersdorf, A., Pérez-López, R., Reicherter, K. (eds.), Seismic Hazard, Critical Facilities and Slow Active Faults: Aachen, Germany, Proceedings of the 4th International INQUA Meeting on Paleoseismology, Active Tectonics and Archeoseismology (PATA), 133-136.

Lacan, P., Ortuño, M., Audin, L., Perea, H., Baize, S., Aguirre-Díaz, G., Zúñiga, R., 2018, Sedimentary evidence of historical and prehistorical earthquakes along the Venta de Bravo Fault System, Acambay Graben (Central Mexico): Sedimentary Geology, 365, 62-77, https://doi.org/10.1016/j. sedgeo.2017.12.008.

Langridge, R.M., Weldon, R.I., Moya, J.C., Suaréz, G., 2000, Paleoseismology of the 1912, Acambay earthquake and the Acambay-Tixmadejé Fault. Trans-Mexican Volcanic Belt: Journal of Geophysical Research, 105 (B2), 3019-3037.

Langridge, R.M., Persaud, M., Zúñiga, F.R., Aguirre-Díaz, G.J., Villamor, P., Lacan, P., 2013, Preliminary paleoseismic results from the Pastores Fault and its role in the seismic hazard of the Acambay graben, Trans-Mexican Volcanic Belt, Mexico: Revista Mexicana de Ciencias Geológicas, 30(3), 463-481.
Lowrie, W., 2007, Fundamentals of Geophysics, 2nd ed; Cambridge University Press, $381 \mathrm{pp}$.

Felix-Maldonado, R., 2017, Modelo estructural del Graben de Acambay a partir de sondeos magnetotelúricos (MT y LMT), gravimetría y aeromagnetometría: Universidad Nacional Autónoma de México, MSc. Thesis, 117 pp.

Martínez-Reyes, J., Nieto-Samaniego, A.F., 1990, Efectos geológicos de la tectónica reciente en la parte central de México: Instituto de Geología, Revista, 9, 33-50.

Miller, H.G., Singh, V., 1994, Semiquantitative techniques for the identification and removal of directional trends in potential field data: Journal of Applied Geophysics, 31 (2-3), 199-211.

Mooser, F., 1972, The Mexican Volcanic Belt-Structure and tectonics: Geofisica Internacional, 12, 55-70.

Ortuño, M., Zúñiga, F.R., Aguirre-Díaz, G.J., Carreón-Freyre, D., Cerca, M., Roverato, M., 2015, Holocene paleo-earthquakes recorded at the transfer zone of two major faults: the Pastores and Venta de Bravo faults (TransMexican Volcanic Belt): Geosphere, 11(1), 160-184.

Ortuño, M., Coromitas, O., Villamor, P., Zúñiga, F.R., Lacan, P., Perea, H., Aguirre-Díaz, G., Štěpančíková, P., Ramirez-Herrera, T., 2018, Evidence of recent ruptures in the central faults of the Acambay Graben (Central Mexico): Geomorphology, doi:10.1016/j.geomorph.2018.07.010.

Pasquarè, G., Ferrari, L., Garduño, V., Tibaldi, A., Vezzoli, L., 1991, Geology of the central sector of the Mexican Volcanic Belt, states of Guanajuato and Michoacán: Boulder, CO, Geological Society of America, Map and Chart Series MCH072, $22 \mathrm{pp}$.

Rodi, W., Mackie, R., 2001, Nonlinear conjugate gradients algorithm for 2-D magnetotelluric inversion: Geophysics 66(1),174-187.

Rodríguez-Pérez, Q., Zúñiga, F.R., Lacan, P., 2017, Paleoseismological uncertainty estimation in the Acambay region, Central Mexico: Geofísica Internacional, 56, 255-268.

Sunye-Puchol, I., Lacan, P., Ortuño, M., Villamor, P., Audin, L., Zúñiga, F.R., Langridge, R.M., Aguirre-Diaz, G., Lawton, T., 2015, La falla San Mateo: Nuevas evidencias paleosismológicas de fallamiento activo en el graben de Acambay, México: Revista Mexicana de Ciencias Geológicas, 32(3), 361-376.

Suter, M., Quintero, O., Johnson, C.A., 1992, Active faults and state of stress in the central part of the Mexican volcanic Belt, the Venta de Bravo fault: Journal of Geophysical Research, 97 (11), 983-994.

Suter, M., Quintero, O., López, M., Aguirre, G., Farrar, E., 1995, The Acambay Graben: Active intra arc extension in the trans-Mexican volcanic belt, Mexico: Tectonics, 14, 1245-1262.

Suter, M., Carrillo-Martínez, M., Quintero-Legorreta, O., 1996, Macroseismic study of earthquakes in the central and eastern parts of the Trans-Mexican Volcanic Belt: Seismological Society of America Bulletin, 86, 1952-1963.

Suter, M., López-Martínez, M., Quintero-Legorreta, O., Carrillo-Martínez, M., 2001, Quaternary intraarc extension in the central Trans-Mexican volcanic belt: Geological Society of America Bulletin, 113, 693-703.

Talwani, M., Worzel, J.L., Landisman, M., 1959, Rapid gravity computations for two-dimensional bodies with applications to the Mendocino submarine fracture zone: Journal of Geophysical Research, 64, 49-59.

Urbina, F., Camacho, H., 1913, La zona megasísmica Acambay-Tixmadejé, Estado de México: Boletín del Instituto Geológico México 32, 1-125.

Velázquez-Bucio, M.M., Garduño-Monroy, V.H., 2018, Soft-sediment deformation structures induced by seismic activity in the San Pedro El Alto area, Acambay graben, Mexico: Revista Mexicana de Ciencias Geológicas, 35(1), 28-40.

Verduzco, B., Fairhead, J.D., Green, C.M., MacKenzie, C., 2004, New Insights into Magnetic Derivatives for Structural Mapping: The Leading Edge, 23, 116-119.

Weaver, J.T., Agarwal, A.K., Lilley, F.E.M., 2000, Characterisation of the magnetotelluric tensor in terms of its invariants: Geophysical Journal International, 141, 321-336.

Manuscript received: april 27, 2018

Corrected manuscript received: july 24, 2018

Manuscript accepted: august 1, 2018 